\title{
Evaluation of the effects of chrysin- omega-3 and quercetin- omega-3 fatty acids complexes on proliferation and apoptosis in A-735 melanomas cell line
} Hamide Malikhan ${ }^{1}$, Elham Siasi Torbati ${ }^{2}$, Ahmad majd $^{3}$, Nematollah Gheibi ${ }^{4}$

1. Ph.D. Student in Molecular Genetic, Department of Genetics, Collage of Sciences, North Tehran Branch, Islamic Azad University, Tehran, Iran. ORCID ID: 0000-0003-1741-4181

2. Assistant Professor, Department of Genetic, Collage of Sciences, North Tehran Branch, Islamic Azad University, Tehran, Iran. ORCID ID: 0000-0003-2204-0508

3. Professor, Department of Biology, Collage of Sciences, North Tehran Branch, Islamic Azad University, Tehran, Iran. ORCID ID: I0000-0003-4272-021X

4.Professor, Cellular and Molecular Research Center, Qazvin University of Medical Sciences, Qazvin, Iran., (Corresponding Author), Tel:028-22302634, Email: gheibi_n@yahoo.com, ORCID ID: 0000-0001-7503-0894

\begin{abstract}
Background and Aim: Recent studies on the treatment of melanoma, have focused on designing efficient methods with low side effects. The aim of the present study was to investigate the effect of quercetin- omega-3 and chrysin- omega-3 complexes on proliferation and apoptosis in the A-375 melanoma cell line.

Materials and Methods: The cells were cultured and then were treated with different concentrations of quercetin- omega-3 and chrysin- omega-3 complexes. MTT assay and flow cytometry were used to evaluate the effects of the above compounds on the rate of cell proliferation and apoptosis.
\end{abstract}

Results: Chrysin- omega-3 and quercetin- omega-3 complexes in the experimental concentrations, inhibited cell growth in a time and concentration-dependent manner. No significant changes in cell growth rate were observed after 24 and 48 hours of treatment with $0-125 \mu \mathrm{M}$ of chrysin- omega-3 complex. However, concentrations of 150,175 , and $200 \mu \mathrm{M}$ chrysin- omega-3 complex significantly decreased the growth of melanoma cells after 24 and $48 \mathrm{~h}(\mathrm{p}<0.05)$. After 72 hours, the inhibitory effect was more potent, so that the inhibitory effect was also seen in lower concentrations $(100$ and $125 \mu \mathrm{m})$. The highest rate of induction of apoptosis was observed after 72 hours $(p<0.05)$. In regard to quercetin- omega-3 complex, the results of the study were similar.

Conclusion: Antiproliferative effects of quercetin- omega-3 and chrysin- omega-3 complexes on melanoma cells are very promising, and suggest these compounds can be considered as potential therapeutic candidates.

Keywords: Melanoma, Quercetin, Chrysin, Omega-3, Apoptosis

Received: Sep 19, $2019 \quad$ Accepted: Oct 3, 2020

How to cite the article: Hamide Malikhan, Elham Siasi Torbati, Ahmad majd, Nematollah Gheibi. Evaluation of the effects of chrysin- omega-3 and quercetin- omega-3 fatty acids complexes on proliferation and apoptosis in A-735 melanomas cell line. SJKU 2021;25(6):35-47.

Copyright $(C 2018$ the Author (s). Published by Kurdistan University of Medical Sciences. This is an open access article distributed under the terms of the Creative Commons Attribution-Non Commercial License 4.0 (CCBYNC), where it is permissible to download, share, remix, transform, and buildup the work provided it is properly cited. The work cannot be used commercially without permission from the journal 
بررسى اثر كميلكس كرايسين و كوئر ستين با اسيد جرب امكا-ـا بر روى ميزان تكثير و ايويتوز

\section{در سلول هاى A-375 ملانوما}

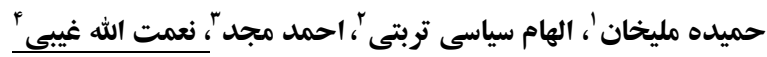

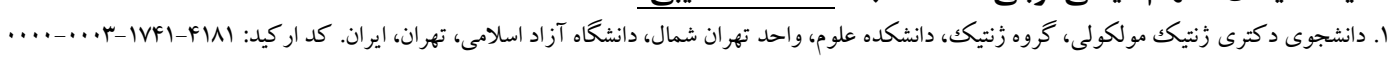

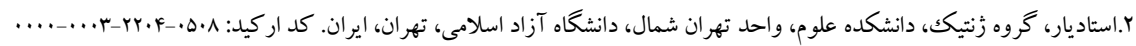

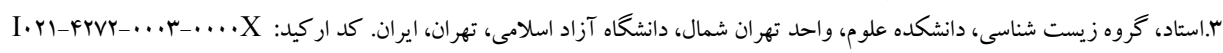

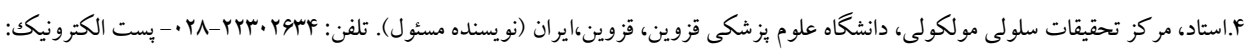

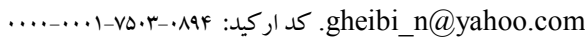

جكيده زمينه و هدف: براى درمان ملانوما، مطالعات اخير بر طراحى روشهاى كار آمد و با عوارض جانبى كم، متمركز شدهاند. هدف

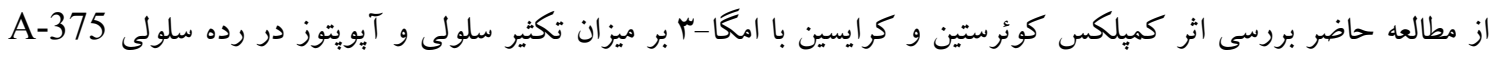
ملانوما مىباشد. مواد و روش ها: سلولهاى رده A-375 ملانوما كشت داده شده، سبس با غلظتهاى مختلف كميلكس كوئرستين و كرايسين

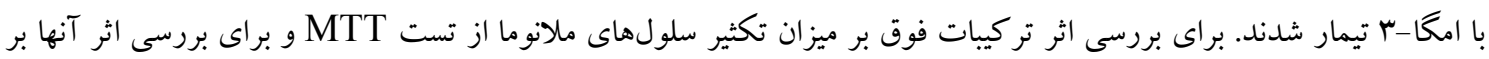
ميز ان آيويتوز از روش فلوسايتومترى استفاده شد.

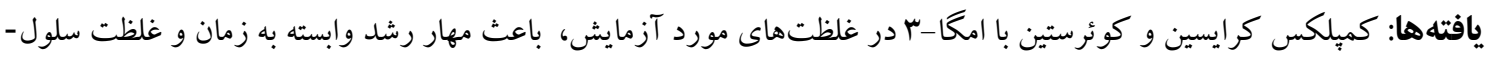

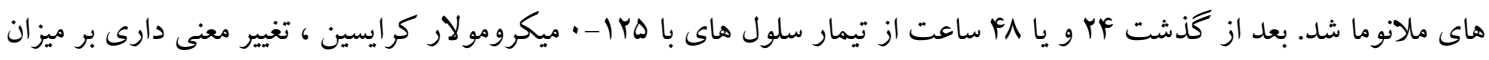

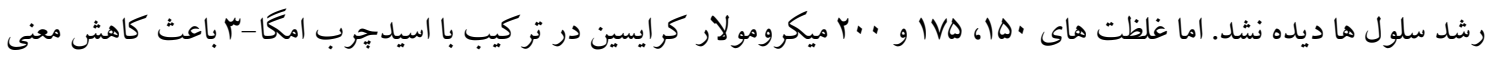

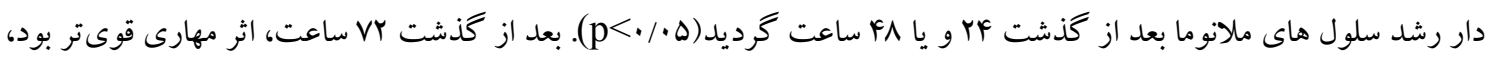

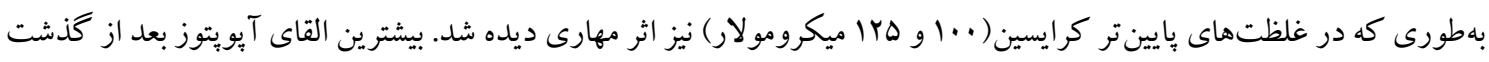

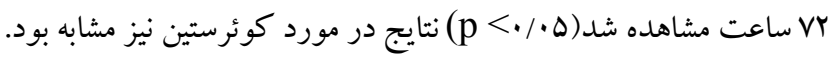

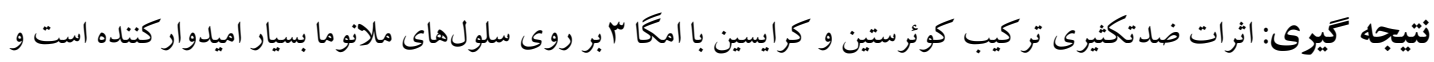

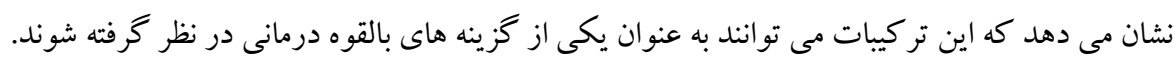
كلمات كليدى: ملانوما، كوئرستين، كرايسين، امكا-با، آيويتوز

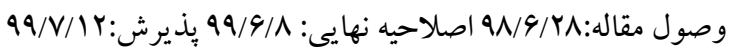


يك از اسيدهاى جرب EPA و DHA به صورت خالص مى تو انند فعاليت ضد نئويلاستيكى انجام دهند، و در بيش كيرى از سرطان و همجينين در درمان آن نقش مهمى داشته

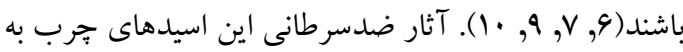
دليل فعاليت آنتىاكسيدانى آنها در بدن است. مطالعات مختلف نشان دادهاند كه اسيدهاى جرب امخا-ب باعث مهار رشد سلولهاى سرطانى، القاء آيويتوز، تعديل بيان زنهاى دخيل در تنظيم بقاى سلولى، و تنظيم مسيرهاى سيكنالينك مرتبط با مرگك و يا رشد سلولى مثل مسير - WNT/B

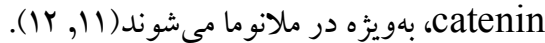
از سوى ديخر، تحقيقات نشان داده است كه فلاونوئدهاى طبيعى مانند كوئرستين و كرايسين مىتواند ززينهاى مناسبى براى درمان ملانوما باشند(rا, (1)). كوئرستين يكى از بلى فنولهاى موجود در رزيم غذايى است كه در ميوهها، سبزيجات و ساير محصولات گياهى از جمله بياز، كلم برو كلى، كلم، يرتقال، زغال اخته، سيب و جاى يافت مى

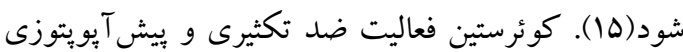
را در انواع مختلف سلولهاى سرطانى نشان داده است. كوئرستين به آسانى توسط تايروزيناز به تركيبات مختلفى تبديل مىشود و همين امر، سبب افزايش فعاليت ضد سرطانى آن مىشود(19). علاوه بر اين، با توجه به اين كه بيان تايروزيناز در طول تومورزايى افزايش مىيابد، و فعاليت آن با تغييرات بيخمنتاسيون در هر دو مرحله ابتدايى و انتهايى آسيبهاى ملانوسيتيك همراه است، بس كوئرستين

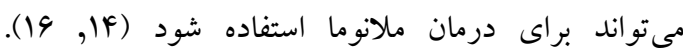

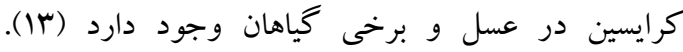
مطالعات نشان دادهاند كه كرايسين از طريق فعالسازى مسير

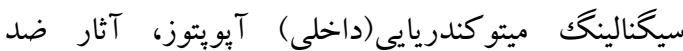
تكثيرى قوى خود را در ملانوما اعمال مى كند(آا, IV). در نتيجه با توجه به اهميت اين دو فلاونوئيد در درمان ملانوما،

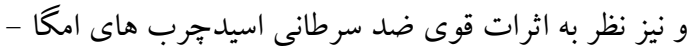
r، هدف يُزوهش حاضر آن است تا اثرات كميلكس
مقدمه

ملانوما تهاجمىترين سرطان بوست است كه منشاء آن از ملانوسيتهاى يوستى، و ايجاد آن عمدتا به دليل اثر برتوهاى فرابنفش است(1). دادههاى إيدميولوزيك،، حاكى از افزايش مداوم و جشم گير بروز اين سرطان در طى دهـهاى كذشته است(Y). از عوامل خطر ديخر، مىتوان خالهاى جند گانه مادرزادى، قرار گرفتن در معرض عوامل سمى و سر كوب سيستم ايمنى بدن را نام برد(Y). همانند اشكال ديخر سرطان، ييشرفت ملانوما با برخى تغييرات مولكولى در سلولهاى سرطانى مرتبط است كه به آنها امكان بايدارى و زنده ماندن به هنكام كمبود مواد مغذى، و مقاومت در برابر شرايط نامساعد را مىدهد(r). اين سلولها مى تواند سيستم ايمنى ميزبان را فريب دهند، در هييو كسى زنده بمانند، استرس اكسيداتيو ايجاد كنند، و درنهايت تمايل روزافزونى براى متاستاز دارند كه خطرناككترين مرحله بيمارى در بيماران ملانوم به شمار مىرود (F). در طى جنائ سال كذشته، درمان ملانوما با معرفى رويكردهاى جديد از بهاز جمله روشهاى هدفمند و ايمونولوزيك، يِيشرفتهاى جشم گيرى را نشان داده است و دوره جديدى در درمان اين نوع سرطان، بيش رو وجود دارد(F).

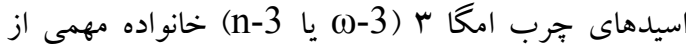
اسيدهاى جرب اشباع نشده Polyunsaturated fatty) و مواد مغذى مهمى هستند كه در رشد acid: PUFAs) طبيعى و توسعه بافتهاى مختلف انسانى نقش دارند (ه-V). اين اسيدهاى جرب اشباع نشده بلند زنجيره، به طور عمده از لهاز

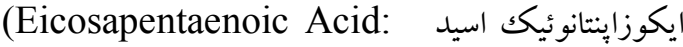
(Docosahexaenoic و وكوزاهگزانوئيك اسيد EPA) تشكيل شدهاند. DHA) acid: دريافت و يا از طريق اكسيداسيون EPA - تامين مىشود Pاى n-3 بهجز نقشى كه در عملكردهاى فيزيولوزيكك دارند، مىتواند بر برخى بيمارىهاى مزمن

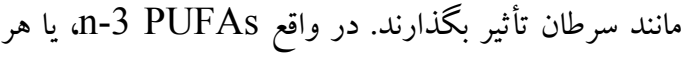


بررسى ميزان آيويتوز با روش فلوسايتومترى: سلولها ( ...... سلول) در مراحل اوليه و انتهايى آيويتوز

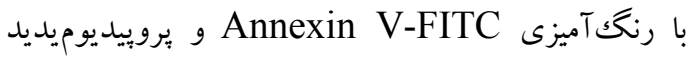
كيت تجارى شركت IQ product و و با استفاده از دستخاه فلوسايتومترى BD FACS Calibur (BD مورد biosciences, San Jose, CA, USA) A-375 شناسايى قرار گرفتند. به طور خلاصه، سلولهاى

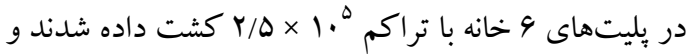

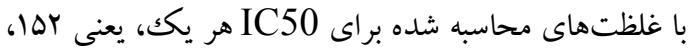

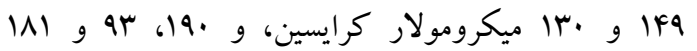

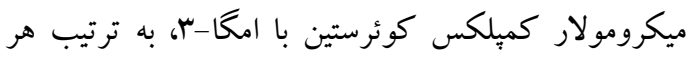

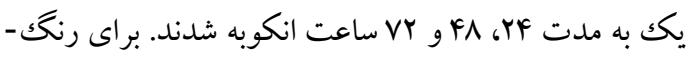
آميزى، سلولها با PBS شسته و با بافر اتصال انكوبه شدند.

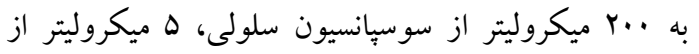

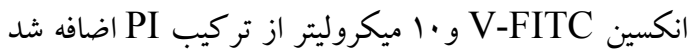
و به مدت ها دقيقه در دماى اتاق و در تاريكى انكوبه شد(1)). سبس سلولها با استفاده از دستگاه فلوسايتومتر مورد تجزيه و تحليل قرار گرفتند. آناليز آمارى: - مورد نجزيه كليه نتايج حاصل از اين مطالعه در رابطه با MTT و

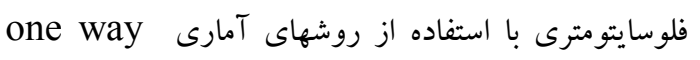
و و مورد تجزيه و تحليل قرار گرفته و نمودارها در هر دو مورد با استفاده از

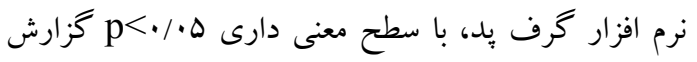

شدهاند.

يافته ها

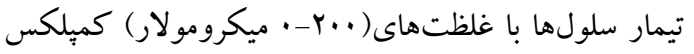

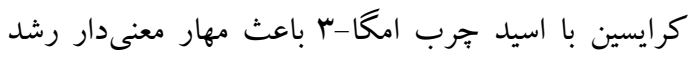

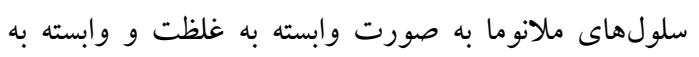

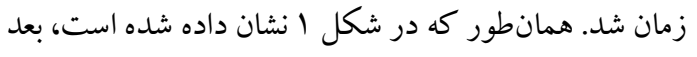

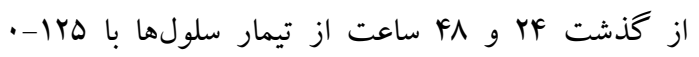

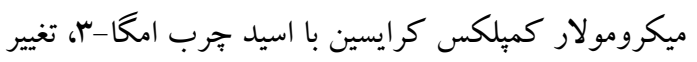

كوئرستين و كرايسين با اسيدهاى جرب امخا-r را در ميزان تكثير و آيويتوز سلولهاى رده

$$
\text { بررسى قرار دهد. }
$$

\section{مواد و روش ها}

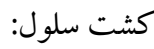
رده سلولى A-375 ملانوما از مجموعه بانكك سلولى انستيتو

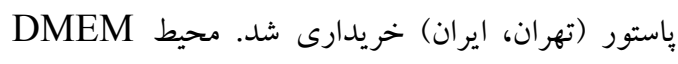
حاوى •اء سرم جنينى غيرفعال شده با گرما و 100U/ml ينى سيلين/استريتومايسين براى كشت سلولها استفاده شد.

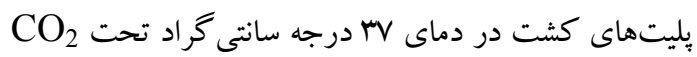
ه\% ن نخهدارى شدند.

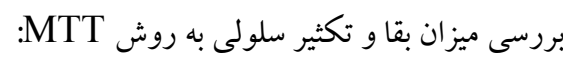

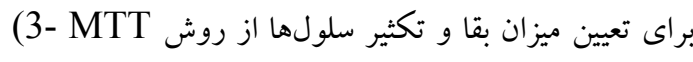
(4,5-dimethylthiazol-2-yl)-2,5diphenyltetrazolium bromide)

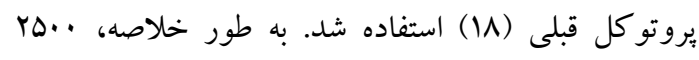
سلول از رده A-375 ملانوما در هر يكك از جاهككهاى

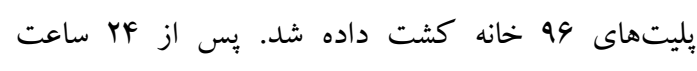

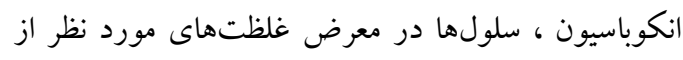

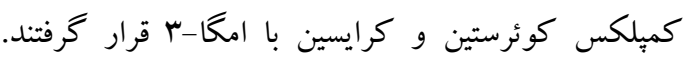
آزمايشات براى هر گروه در سه تكرار و با گروه كنترل

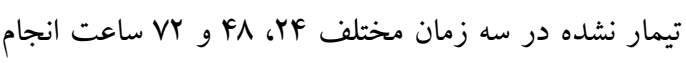

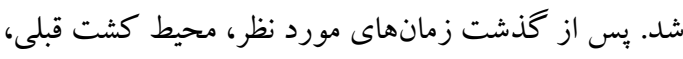

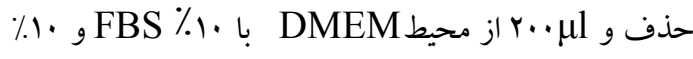
(سيخما، ايالات متحده) اضافه شد. MTT (5 mg/mL)

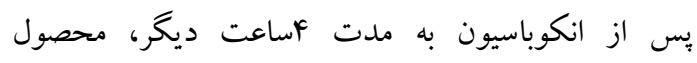

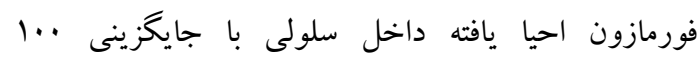

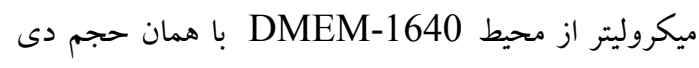

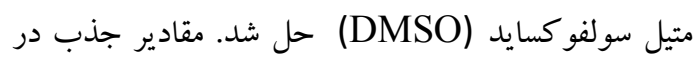

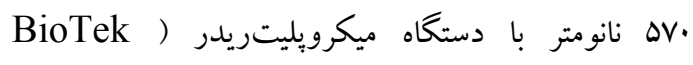
(ELX800, USA نصف حداكثر (IC50) از هر آزمايش محاسبه شد. 
ولى كميلكس كوئرستين با امخا ب در همين زمانها، در

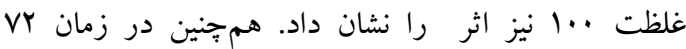

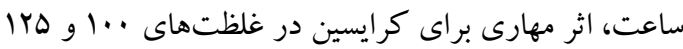
نيز مشاهده شد كه اين امر در مورد كوئرستين مربوط به براسئ غلظت بايينتر يعنى VD ميكرومولار بود. در مرحله بعد،

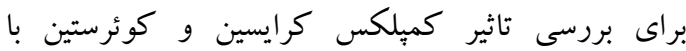

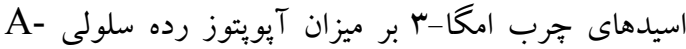
375 ملانوما، از روش فلوسايتومترى با انكسين-V استفاده شد. ابتدا سلولها با غلظتهاى محاسبه شده براى IC50

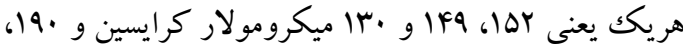
به و اماميكرومولار كميلكس كوئرستين با اسيد خرب

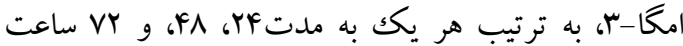
تيمار شدند. همانطور كه در شكل ب نشان داده شده است،

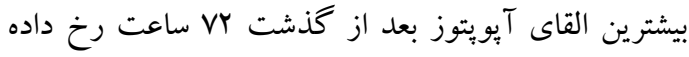

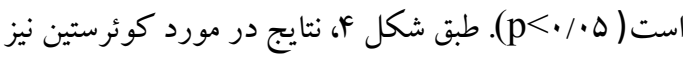
مشابه بود و تيمار سلول ها به مدت ملاساعت اثر قوى ترى

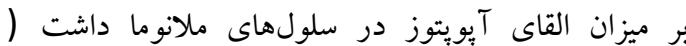
(p<•/• كميلكس كرايسين يا كوئرستين با اسيدهاى جرب امخا-r با غلظتهاى فوق باعث القاى معنىدار آيويتوز به صورت وابسته به زمان و غلظت گرديد؛ بهطورى كه قوى ترين اثر بعد از كذشت VI ساعت و در غلظتهاى بالاتر ديده شد (شكل ه)
معنى دارى در ميزان رشد سلولها ديده نشد. اما غلظتهاى 1D. اسيدجرب امخا-r باعث كاهش معنىدار رشد سلولهاى

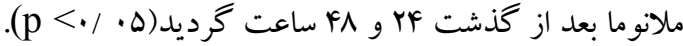
بعد از كذشت VI ساعت اثر مهارى قوى تر بود، به طورى-

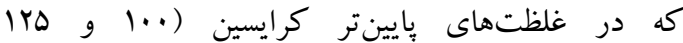
ميكرومولار) نيز اثر مهارى ديده شد. يافتهاى حاصل در مورد كميلكس كوئرستين با اسيد جرب امخا-ب نيز مشابه بود. اثرات مهارى اين تركيب نيز وابسته به غلظت و زمان

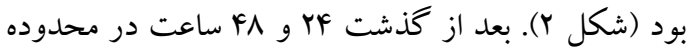

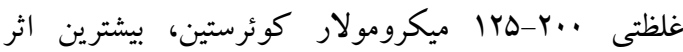
مهارى بر ميزان رشد سلولى سلولهاى ملانوما ديده شد

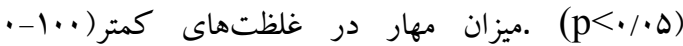

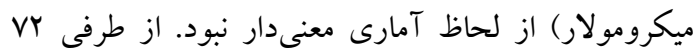

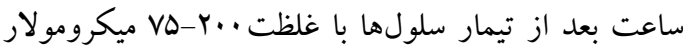

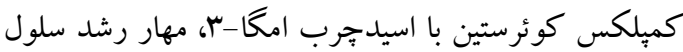
ها ازلحاظ آمارى معنىدار بود كه نشان دهنده اثرات قوىتر در مقايسه با FF و YF ساعت تيمار مى باشد. با مقايسه نتايج

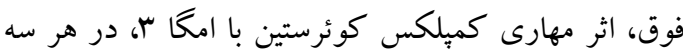
زمان مورد مطالعه، بيشتر از اثر مهارى كمبلكس كرايسين با فيأ

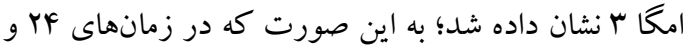
M M Mاعت، كميلكس كرايسين با امكا r در غلظتهاى

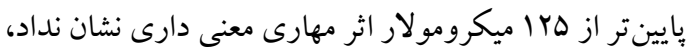



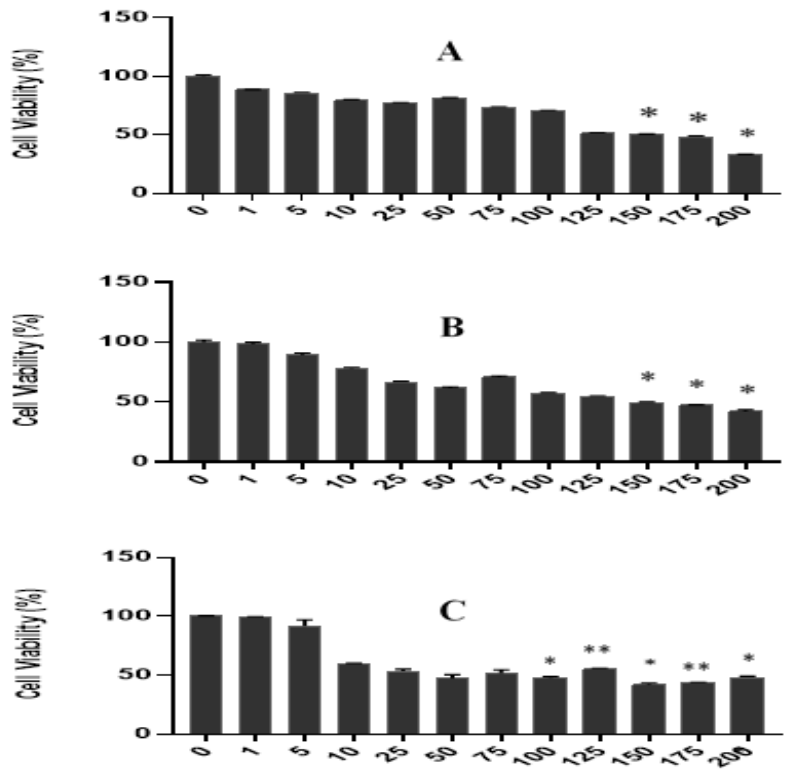

AlA + Chrysin Concentration $(\mu \mathrm{m})$

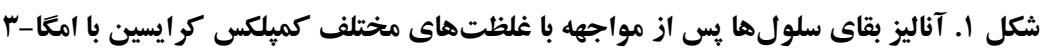

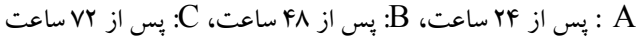
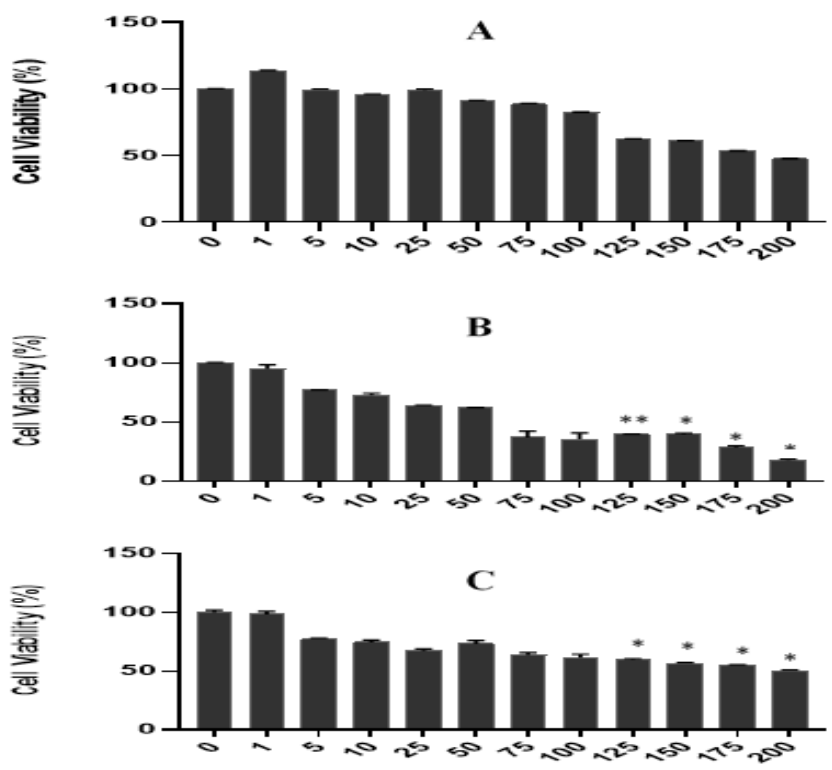

AlAtQuercetin Concentration(um)

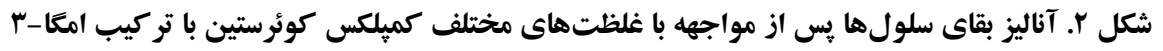
A 
A

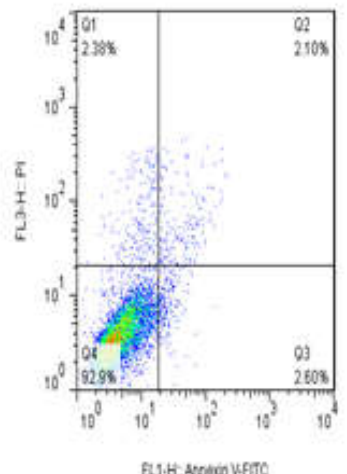

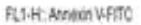

D

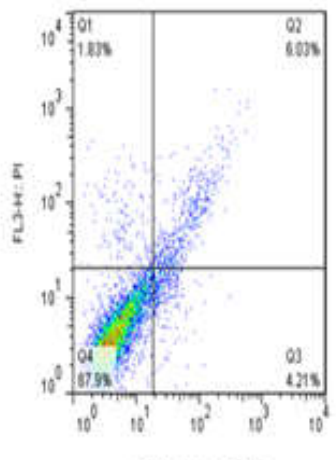

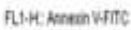

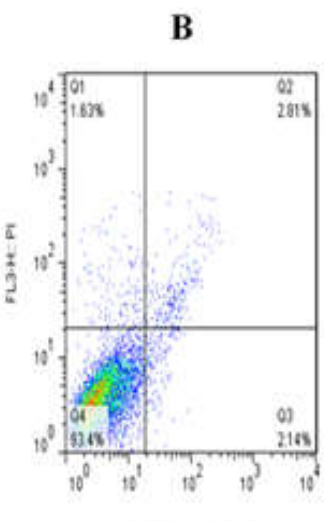

FLIH: AmetiousGC

E

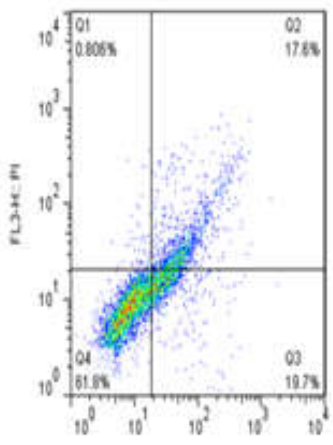

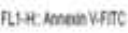

C
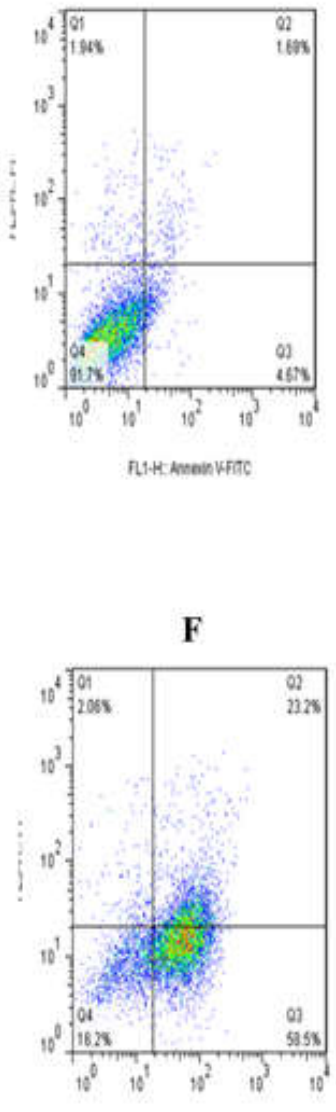

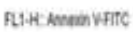

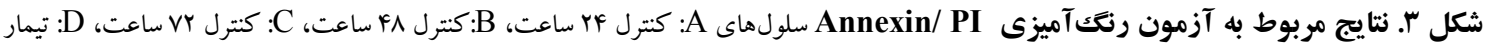

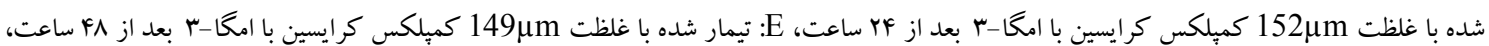

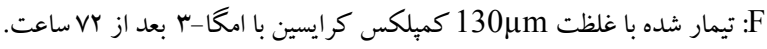

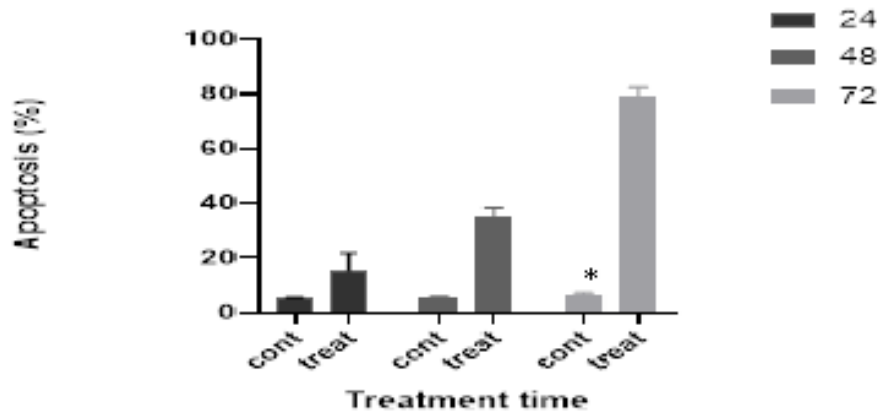

شكل F. مقايسه ميزان آبويتوز سلولهاى تيمارشده با غلظتهاى

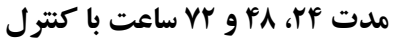



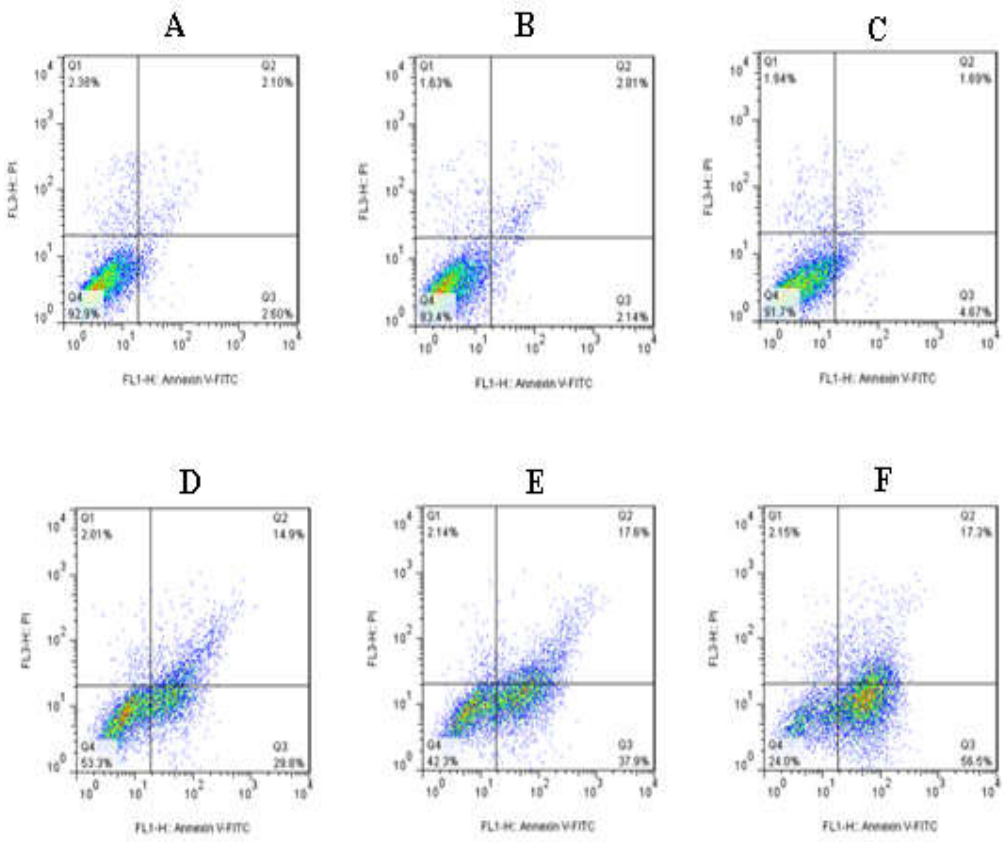

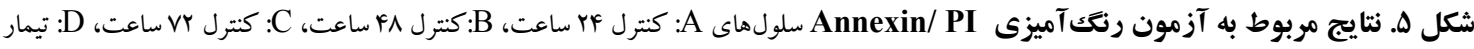

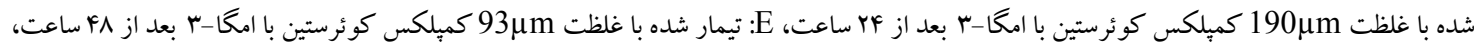
F تيمار شده با غلظت F

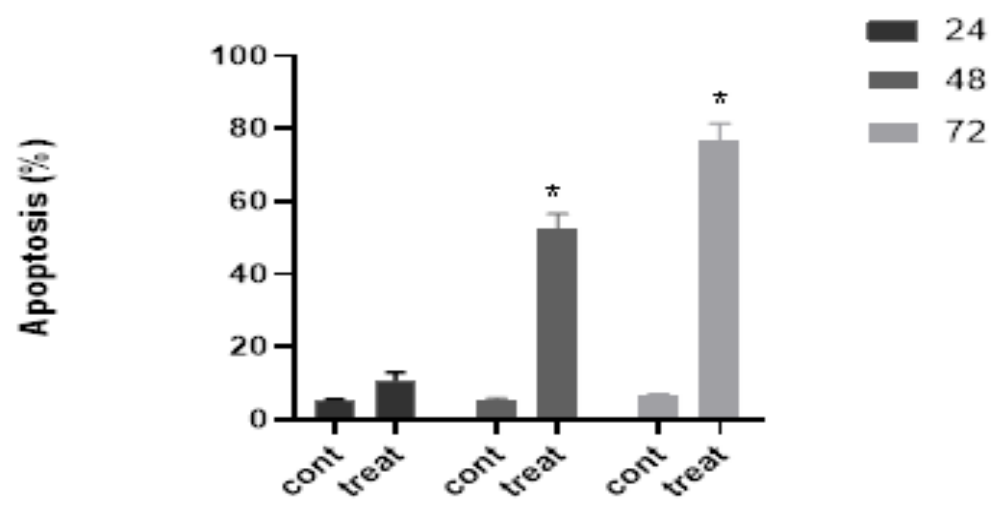

Treatment time

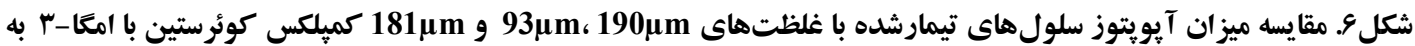

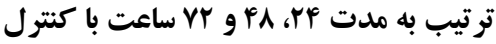

به زمان و غلظت شد. از طرفى اين تركيبات باعث القاى قوى آيويتوز نيز شدند. در دهه كذشته نتايج مطالعات در مطالعه حاضر، تيمار سلولهاى A-375 ملانوما با ابيدميولوزيكك بيانكر اثرات مهارى اسيدهاى جرب امخًا-ب

غلظتهاى مختلف كمبركس كرايسين و كوئرستين با اسيدهاى جرب امكا-با، باعث مهار رشد به صورت وابسته 
يروتئازوم را افزايش ميدهند؛ در حالى كه اسيدهاى جرب

اشباع ، عملكرد متضادى دارند(Y9).

بيوسنتز ملانين و ساير رنگدانهها در ملانوسيتها توسط

آنزيمى حاوى مس به نام تايروزيناز، كاتاليز مىشود(19,

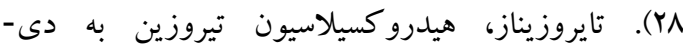

هيدرو كسى فنيل آلانين L-DOPA) و L-DOPA) به Lيه

دوياكوئينين را كاتاليز مى كند. كوئينونها به نوبه خود به

ملانين و ديخر تركيبات بلىفنولى تبديل مىشوند(Yq). سنتز

ملانين سبب توليد يراكسيد هيدروزن و ديخر گونههاى فعال

اكسيزن(ROS) شده و اين امر سبب مىشود ملانوسيتها

تحت استرس شديد اكسيداتيو قرار بكيرند.( •().

در ميان تركيبات طبيعى، فلاونوئيدها، تر كيباتى يلى فنولى با وزن مولكولى كم و از لحاظ شيميايى داراى ساختار فنيل بنزوييرون (C6- C3-C6) هستند و بر اساس سطح اشباع، جانشينى حلقه C و باز بودن حلقه مركزى بيرون به كروههاى مختلفى تقسيم مى شوند( آM). مطالعات بيولوزيكى و فارماكولوزيكى نشان مىدهند كه يلىفنولهاى رزيم غذايى، مانند كوئرستين و كرايسين، داراى ويز گَى هاى آنتى اكسيدانى، ضد التهابى، ضد جاقى، ضد سرطانى و

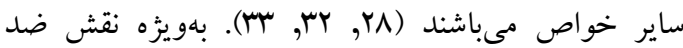
سرطانى كوئرستين و كرايسين به طور كسترده در شرايط آزمايشگاهى مورد بررسى قرار گرفته است (YY). اتيولوزى

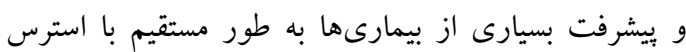
اكسيداتيو ناشى از عدم تعادل بين تشكيل و خنثىسازى اكسيدانها، مرتبط است (هـ-Nم). اثرات مفيد كوئرستين بر روى بافتهاى طبيعى به مكانيسمهاى مختلف، به ويزه اثرات آنتى اكسيدانى آن نسبت داده شده است. در خانواده فلاونوئيدها، كوئرستين قوىترين آنتىاكسيدان در برابر كونهاى اكسيداتيو واكنشيذير (ROS) است و ظرفيت آنتى اكسيدانى آن عمدتا به دليل وجود گرووهاى هيدروكسيل روى حلقه فنلى B است (qr). اثرات ضد سرطانى كوئرستين در سرطانهاى روده بزرگ، كبد و
در سرطانهاى مختلف مىباشد. به عنوان مثال، تيمار سلول هاى سرطانى كولور كتال با اسيدهاى جرب امگًا-ب موجب مهار رشد سلولها و القاى آيويتوز با تجمع سلولها در فاز

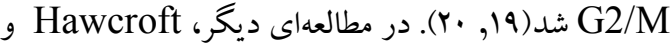
همكارانش با تيمار سلولهاى سرطانى روده بزرگك با اسيدهاى جرب امخًا-r باعث كاهش رشد تومور و كاهش تكثير سلولهاى سرطانى شدند(Y). Sam و همكاران در مطالعهاى بر روى سلولهاى سرطانى خون نشان دادند كه اسيدهاى جرب امخا-ب به صورت وابسته به زمان و وابسته لروبه به غلظت باعث مهار سلولهاى سرطانى مىشوند (YY). نتايج مشابه در سرطان ملانوما نيز مشاهده شده است كه در آن، تيمار سلولهاى سرطانى ملانوما با اسيدهاى جرب امگًا-ب باعث مهار قوى سلولهاى سرطانى و القاى آيويتوز و نيز مهار متاستاز شده است(سY). رحمانى و همكاران نيز در "ثزوهش خود، علاوه بر بررسى اثر اسيدهاى جرب امخًا-س بر روى بيان زن Wt-1 ، اثر آنتىيروليفريتيو آن بر روى سلولهاى رده MIA PaCa-2 (سرطان يانكراس) را در غلظت هاى ..1 تا ...1 ميكرومولار نشان دادند(YF). در مطالعهاى ديخر، اسيدهاى جرب امخا-ب و امخا-4 اثر قابل توجهى بر بقاى سلولهاى SKOV-3 (سلولهاى سرطانى تخمدان) نشان ندادند ولى قادر به القاى آيوتوز در آنها بودند؛ اين مطالعه بيشنهاد داد اثر اين اسيدهاى جرب بر بقاى سلولها بستكى به غلظت آنها و هم جنين بستكى به نوع سلول مورد مطالعه دارد؛ به اين صورت كه در غلظتهاى

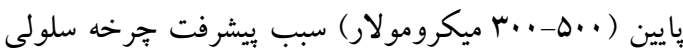
ودر غلظتهاى بالاى ... ميكرومولار سبب مهار رشد سلولهاى SKOV-3 مىشود. غلظت هاى مشخصى از اسيدهاى جرب قادر به (Critical concentration) مقابله با سلولهاى سرطانى خواهند بود كه اين غلظت به نوع سلول و نوع اسيد جرب بستكى دارد(YO). هم جنين اسيدهاى خرب غير اشباع، تخريب تايروزيناز توسط كميلكس 
تكثيرى زيادى دارد ولى استفاده از آن به دليل اين كه مستعد اكسيداسيون است، محدود است؛ تركيب اسيدهاى خرب غير اشباع با فلاونوئيدهاى مشخصى با خواص آنتى

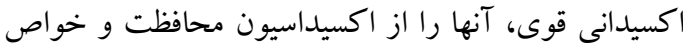

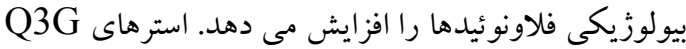
خواص آنتىاكسيدانى تشديد يافتهاى به خاطر افزايش

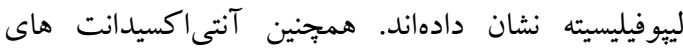
لييوفيليك و هيدروفوبيك، در محيطهاى با لييوفيليسيته مختلف، اثرات متفاوتى خو اهند داشت(FD). مطالعات نشان دادهاند علاوه بر كوئرستين، كرايسين نيز يك آن تركيب بلىفنولى قوى با اثرات مهارى بر روى سلولهاى سرطانى مختلف به ويزٔه ملانوما مى باشد. براى مثال، Xue و همكاران گزارش كردهاند كه كرايسين باعث مهار رشد سلولهاى سرطانى ملانوما بدون تاثير بر روى سلولهاى سالم از طريق فعالسازى مسير ميتو كندريايى آيويتوز مى شود(rا). از طرفى، Sassi و همكاران نيز نشان دادند كه در مدل حيوانى و نيز رده هاى سلولى ملانوما، كرايسين

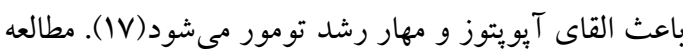

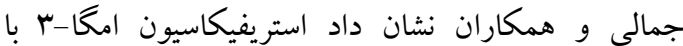
كرايسين اثر مهارى از نوع رقابتى بر روى تايروزيناز قارجى ساري

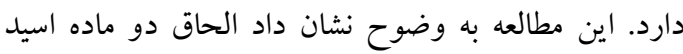

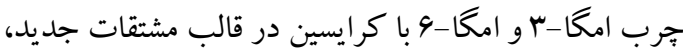
آثار مهارى قوى ترى نسبت به هر يك از اين تركيبات به

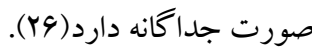

\section{نتيجه كيرى}

در يزوهش حاضر، براى اولين بار اثر كمبلكس كوئرستين و

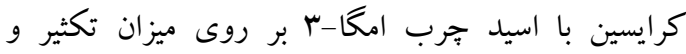

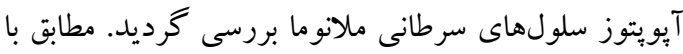
مطالعات فوق، اين مطالعه كاهش معنى دار تكثير در اين سلولها به صورت وابسته به زمان و غلظت را نشان داد. هم جنين بررسى نتايج حاصل از تكنيك فلوسايتومترى، بعد از تيمار سلول ها با اين تركيبات، افزايش معنى دار مركى تحنى
ملانوما نيز به طور مستقيم با خصوصيات آنتىاكسيدانى آن مرتبط است. كوئرستين مهار كننده قوى رشد سلولهاى سرطانى ملانوما و القا كننده آيويتوز مىباشد(••). مطالعات نشان دادهاند كه اثرات كوئرستين به غلظت آن در بافت، نحوه متابوليسم و دسترسى زيستى به آن بستخى دارد (Fr). در مطالعه راياسينگ و همكاران با عنوان بررسى فعاليت

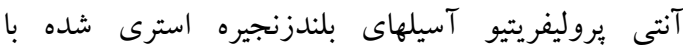
كوئرستين كلو كوزيد (Quercetin-3-O-glucoside) بر سلولهاى HepG2 كارسينوماى هياتوسلولار، شش اسيد جرب از جمله EPA و DHA با كوئرستين-r-Oت كلوكوزيد (فرم رايج كوئرستين دركياهان) بصورت آنزيماتيك، استريفيه شده و اثرات آنتى يروليفراتيو آنها بر

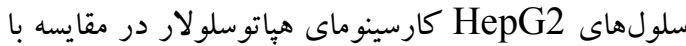
دو داروى شيمى درمانى به نامهاى سيس بِلاتين و سورافنيب، بررسى گرديد. نتايج اين مطالعه نشان داد كه استر اسيدهاى خرب با كوئرستين گلو كوزيد، اثر مهارى قابل توجهى بر سلولهاى HepG2 داشت؛ به طورى كه

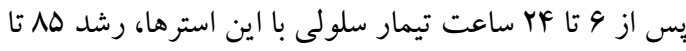

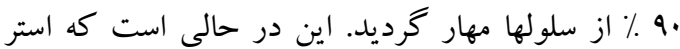
اسيدهاى هرب با كوئرستين گلوكوزيد، نسبت به داروى

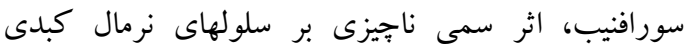
داشت (FF). در مطالعهاى ديخر، استرهاى EPA, DHA و

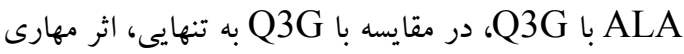

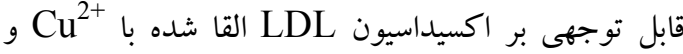
راديكال بر اكسيل داشتند. در نهايت، نتايج اين مطالعه نشان داد كه استريفيكاسيون خاصيت لييوفيليسيته آنتى اكسيدانت ها را افزايش داده، كوئرستين استريفيه شده با اسيدهاى جرب، لييوفيليسه بيشترى از كوئرستين غير كونزو گه داشته، و قدرت بيشترى براى مهار اكسيداسيون ليبيدهايى مانند LDL افزايش لييوفيليسيته دسترسى زيستى فلاونوئيدها را تحت تاثير قرار مى دهد و مى تواند جذب سلولى و در نتيجه

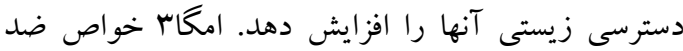




$$
\begin{aligned}
& \text { سلولى به روش آيويتوز را به صورت وابسته به غلظت و تر نسبت به كرايسين مشاهده شد.به اين ترتيب استفاده از }
\end{aligned}
$$

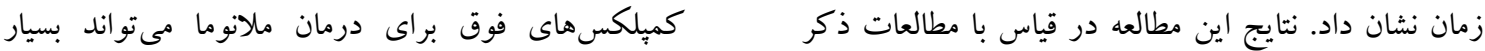

$$
\begin{aligned}
& \text { شده، نشان مىدهد كه عملكرد ضد تومورى كميلكس اميدبخش باشد. لذابررسى اثرات ضد تومورى اين تركيبات }
\end{aligned}
$$

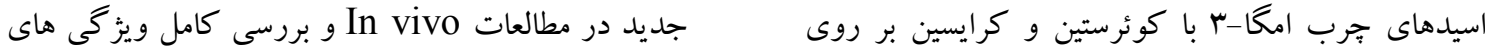

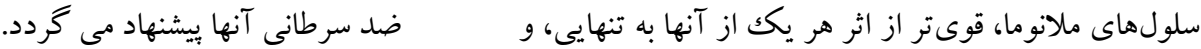

$$
\begin{aligned}
& \text { همجنين اثر كميلكس كوئرستين با امخاس، قوى تر از اثر }
\end{aligned}
$$

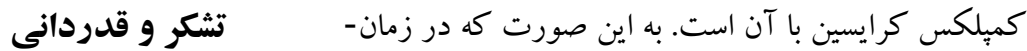

$$
\begin{aligned}
& \text { ضمن سياس و قدردانى از حمايت معاونت تحقيقات و }
\end{aligned}
$$

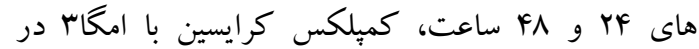

$$
\begin{aligned}
& \text { غلظتهاى پِيين فاقد اثر مهارى معنىدار، ولى كميلكس } \\
& \text { كوئرستين با امخاس در اين زمانها، با وجود غلظت بايينتر، } \\
& \text { واجد اثر مهارى بر سلولهاى ملانوما بود. همجنين ، اثر } \\
& \text { مهارى براى كوئرستين در زمان VY ساعت، در غلظتى بايين - } \\
& \text { IR.QUMS.REC.1397.329 مىباشد. }
\end{aligned}
$$

1.Geller AC, Clapp RW, Sober AJ, Gonsalves L, Mueller L, Christiansen CL, et al. Melanoma epidemic: an analysis of six decades of data from the Connecticut Tumor Registry. J Clin Oncol. 2013;31(33):4172.

2.Mattia G, Puglisi R, Ascione B, Malorni W, Carè A, Matarrese P. Cell death-based treatments of melanoma: conventional treatments and new therapeutic strategies. Cell Death Dis. 2018;9(2):112.

3.Apalla Z, Lallas A, Sotiriou E, Lazaridou E, Ioannides D. Epidemiological trends in skin cancer. Dermatol Pract Concept. 2017;7(2):1.

4.Matarrese P, Ascione B, Ciarlo L, Vona R, Leonetti C, Scarsella M, et al. Cathepsin B inhibition interferes with metastatic potential of human melanoma: an in vitro and in vivo study. Mol cancer. 2010;9(1):207.

5.Burlingame B, Nishida C, Uauy R, Weisell R. Fats and fatty acids in human nutrition: introduction. Ann Nutr Metab. 2009;55(1-3):5-7.

6.Riediger ND, Othman RA, Suh M, Moghadasian MH. A systemic review of the roles of n-3 fatty acids in health and disease. J Am Diet Assoc. 2009;109(4):668-79.

7.Calder PC. Marine omega-3 fatty acids and inflammatory processes: effects, mechanisms and clinical relevance. Biochim Biophys Acta. 2015;1851(4):469-84.

8.Abdi J, Garssen J, Faber J, Redegeld F. Omega-3 fatty acids, EPA and DHA induce apoptosis and enhance drug sensitivity in multiple myeloma cells but not in normal peripheral mononuclear cells. J Nutr Biochem. 2014;25(12):1254-62.

9.Molfino A, Amabile MI, Mazzucco S, Biolo G, Farcomeni A, Ramaccini C, et al. Effect of oral docosahexaenoic acid (DHA) supplementation on DHA levels and omega-3 index in red blood cell membranes of breast cancer patients. Front Physiol. 2017;8:549.

10.Bhagat U, Das UN. Potential role of dietary lipids in the prophylaxis of some clinical conditions. Arch Med Sci. 2015;11(4):807. 


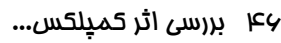

11.Serini S, Zinzi A, Vasconcelos RO, Fasano E, Riillo MG, Celleno L, et al. Role of $\beta$ catenin signaling in the anti-invasive effect of the omega-3 fatty acid DHA in human melanoma cells. J Dermatol Sci. 2016;84(2):149-59.

12.Serini S, Fasano E, Piccioni E ,Monego G, Cittadini AR, Celleno L, et al. DHA induces apoptosis and differentiation in human melanoma cells in vitro: involvement of HuRmediated COX-2 mRNA stabilization and $\beta$-catenin nuclear translocation. Carcinogenesis. 2011;33(1):164-73.

13.Xue C ,Chen Y, Hu DN, Iacob C, Lu C, Huang Z. Chrysin induces cell apoptosis in human uveal melanoma cells via intrinsic apoptosis. Oncol Lett. 2016;12(6):4813-20.

14.Harris Z, Donovan MG, Branco GM, Limesand KH, Burd R. Quercetin as an emerging anti-melanoma agent: a four-focus area therapeutic development strategy. Front Nutr. 2016;3:48.

15.Russo GL, Ungaro P. Epigenetic Mechanisms of Quercetin and Other Flavonoids in Cancer Therapy and Prevention. Epigenetics of Cancer Prevention: Elsevier; 2019. 187-202.

16.Kubo I, Nitoda T, Nihei K-i. Effects of quercetin on mushroom tyrosinase and B16-F10 melanoma cells. Molecules. 2007;12(5):1045-56.

17.Sassi A, Maatouk M, Bzéouich IM, Hatira SA-B, Jemni-Yacoub S, Ghedira K, et al. Chrysin, a natural and biologically active flavonoid suppresses tumor growth of mouse B16F10 melanoma cells: In vitro and In vivo study. Chem Biol Interact. 2018;283:10-9.

18. Yousefi R, Imani M, Ardestani SK, Saboury AA, Gheibi N, Ranjbar B. Human calprotectin: effect of calcium and zinc on its secondary and tertiary structures, and role of $\mathrm{pH}$ in its thermal stability. Acta Biochim Biophys Sin. 2007;39(10):795-802.

19.Jordan A, Stein J. Effect of an omega-3 fatty acid containing lipid emulsion alone and in combination with 5-fluorouracil (5-FU) on growth of the colon cancer cell line Caco-2. Eur J Nutr. 2003;42(6):324-31.

20.Kalbkhani F, Sam MR. The effect of fish-oil derived eicosapentaenoic acid on cell proliferation and caspase- 3 activity in human colorectal cancer cell line. Tehran Univ Med J. 2018;76(6):374-9.

21.Hawcroft G, Loadman PM, Belluzzi A, Hull MA. Effect of eicosapentaenoic acid on Etype prostaglandin synthesis and EP4 receptor signaling in human colorectal cancer cells. Neoplasia. 2010;12(8):618.

22.Sam MR, Esmaeillou M, Sam S, Shokrgozar MA. Fish-oil-derived eicosapentaenoic acid decreases survivin expression and induces wt-p53 accumulation with caspase- 3 activation in acute lymphoblastic leukemia cells. Hum Exp Toxicol. 2018;37(7):714-24.

23.Li J, Chen CY, Arita M, Kim K, Li X, Zhang H, et al. An omega-3 polyunsaturated fatty acid derivative, 18-HEPE, protects against CXCR4-associated melanoma metastasis. Carcinogenesis. 2018;39(11):1380-8.

24.Rahmani B, Naserpour Farivar T, Azad M, Sahmani M, Gheibi N. The effects of omega-3 PUFA (ALA) on WT1 gene expression in pancreatic cancer cell line (MIA PaCa-2). World Family Medicine. 2018;16(2):275-281.

25.Hajighasemi S, Azad M, Karimipoor M, Rahimi H, Foroughi F, et al. (2018) Dual Effects of Omega -6, and -9 Fatty Acids on Ovarian Cancer Cell Viability and Their Ability to Induce Apoptosis. Adv Proteomics Bioinform: APBI-106. DOI: 10.29011/APBI -106.100006

26.Jamali Z , Zare K, Gheibi N. Effect of chrysin omega-3 and 6 fatty acid esters on mushroom tyrosinase activity, stability, and structure. J Food Biochem. 2018;e12728. 
27. Metodiewa D, Jaiswal AK, Cenas N, Dickancaite E, Segura-Aguilar J. Quercetin may act as a cytotoxic prooxidant after its metabolic activation to semiquinone and quinoidal product. Free Radic Biol Med. 1999;26:107-116.

28. Gheibi N, Taherkhani N, Ahmadi A, Haghbeen K, Ilghari D. Characterization of inhibitory effects of the potential therapeutic inhibitors, benzoic acid and pyridine derivatives, on the monophenolase and diphenolase activities of tyrosinase. Iran $\mathrm{J}$ Basic Med Sci. 2015;18(2):122-9.

29.Baharara J, Tayarani Najjaran Z, Amini E, Salek F. The Inhibitory Effect of Crocin on Melanogenesis of B16F10 Melanoma Cell Line. JSSU. 2016; 24 (6) :479-490.

30.Abdolmaleki F, Gheibi N, Ahmadpour Yazdi H. Inhibitory Effect of Myricetin on Melanoma Cells (A375). Novel Biomed. 2017;5(3):104-8.

31.Wang L, Tu YC, Lian TW, Hung JT, Yen JH, Wu MJ. Distinctive antioxidant and antiinflammatory effects of flavonols. J Agric Food Chem. 2006; 54(26):9798-804.

32.Rice-Evans CA, Miller NJ, Paganga G. Structure-antioxidant activity relationships of flavonoids and phenolic acids. Free Radic Biol Med. 1996;20:933-956.

33.Nam JS, Sharma AR, Nguyen LT, Chakraborty C, Sharma G, Lee SS. Application of Bioactive Quercetin in Oncotherapy: From Nutrition to Nanomedicine. Molecules. 2016; 21(1):E108.

34.Dhalla NS, Temsah RM, Netticadan T. Role of oxidative stress in cardiovascular diseases. J Hypertens. 2000; 18(6):655-73.

35.Uttara B, Singh AV, Zamboni P, Mahajan RT. Oxidative stress and neurodegenerative diseases: a review of upstream and downstream antioxidant therapeutic options. Curr Neuropharmacol. 2009;7(1):65-74.

36.Reddy VP, Zhu X, Perry G, Smith MA. Oxidative stress in diabetes and Alzheimer's disease. J Alzheimers Dis. 2009;16(4):763-74.

37.Locatelli F, Canaud B, Eckardt KU, Stenvinkel P, Wanner C, Zoccali C. Oxidative stress in end-stage renal disease: an emerging threat to patient outcome. Nephrol Dial Transplant. $2003 \mathrm{Jul} ; 18(7): 1272-80$.

38. Murota K, Terao J. Antioxidative flavonoid quercetin: implication of its intestinal absorption and metabolism. Arch Biochem Biophys. 2003 ;417(1):12-7

39. Tanigawa S, Fujii M, Hou DX. Stabilization of p53 is involved in quercetin-induced cell cycle arrest and apoptosis in HepG2 cells. Biosci Biotechnol Biochem. 2008;72(3):797-804.

40.Ranelletti FO, Maggiano N, Serra FG, Ricci R, Larocca LM, Lanza P, Scambia G, Fattorossi A, Capelli A, Piantelli M. Quercetin inhibits p21-RAS expression in human colon cancer cell lines and in primary colorectal tumors. Int J Cancer. 2000; 85(3):438-45.

41.Soengas MS, Lowe SW. Apoptosis and melanoma chemoresistance. Oncogene. 2003; 22(20):3138-51.

42.Awad HM, Boersma MG, Vervoort J, Rietjens IM. Peroxidase-catalyzed formation of quercetin quinone methide-glutathione adducts. Arch Biochem Biophys. 2000; 378(2):22433.

43.Sudan S., Rupasinghe H. V. Antiproliferative activity of long chain acylated esters of quercetin-3-O-glucoside in hepatocellular carcinoma HepG2 cells. Exp. Biol. Med. 2015; 240(11): 1452-64.

44.Warnakulasuriya SN, Ziaullah, Rupasinghe HP. Long chain fatty acid acylated derivatives of quercetin-3-o-glucoside as antioxidants to prevent lipid oxidation. Biomolecules. 2014; 4(4):980-93 